\title{
Szabadgyökök és antioxidánsok
}

10.21486/recreation.2011.1.4.2

A szabadgyökök természetes velejárói életünknek, amelyek belső és külső körülmények hatására keletkeznek. Belső lehet például az abiotikus stressz, a külsők közül megemlithetőek a különböző stresszhatások, környezetszennyezés, dohányzás. A szabadgyökök ellen megfelelő védelmet az antioxidánsok nyújtanak, melyek egy részét a szervezet termeli meg, de előfordulnak olyanok is, melyeket csak a táplálkozással tudunk bejuttatni. Fontos antioxidánsok a C-vitamin, E-vitamin, karotinoidok. Ezen felül magas antioxidáns-tartalommal rendelkeznek a gyümölcsök is. Érdekes módon nemcsak káros hatások által keletkezhetnek, hanem a testedzés is egy magasabb szabadgyöktermelés beindítását eredményezi, de akkor beindul a megfelelő antioxidáns-termelés, ezzel mintegy ellenállóbbá téve a szervezetet. Az utóbbi időben egyre több módszer terjedt el az élelmiszerek és különböző biológiai rendszerek mérésével kapcsolatban, melyeknek napjainkra már több száz variánsa terjedt el. Két nagy csoportra oszthatjuk őket: hidrogénatom-átmenettel és elektronátmenettel kapcsolatos módszerekre. Az antioxidáns-bevitelt azért helyén kell kezelni, ugyanis a sok felborithatja az emberi szervezet természetes védekezőképességét, a túl kevésse pedig elmulaszthatjuk bizonyos betegségek kivédését. Az antioxidáns jótékony hatását már kutatásokkal is igazolták. Például az életkristály nevủ természetes alapanyagokból készült, magas antioxidáns-tartalommal rendelkező elixír a betegek 80 százalékánál jótékony hatást mutatott ki az erek rugalmasságával kapcsolatban. Kulcsszavak: antioxidáns, szabadgyök.

A sejtekben természetes körülmények között lejátszódó biokémia folyamatok, jellemzően az oxidációs folyamatok során keletkezne szabadgyökök, amelyek egy bizonyos részének fontos szerepe van a szervezet normális müködésének fenntartásában, többek között a sejtciklus szabályozásában, a sejt metabolitikus folyamataiban, illetve a szervezet védekezőmechanizmusában (Davies, 2000). A szabadgyökök olyan reaktiv oxigén-, nitrogén-, kén-vagy szénközpontú molekulák, illetve molekularészletek, amelyek párositatlan elektronnal rendelkeznek, ezért rendkivül agresszivak és rövid életidejüek, hiszen nagyon gyorsan kémiai reakcióba lépnek más vegyületekkel elektronszerzés céljából (Cadenas, 1989). A szabadgyökök képződése a normális anyagcsere-folyamatokhoz, igy a terminális oxidációhoz köthető, másrészt a szervezetben lejátszódó biokémiai reakciók következményel:
„A szabadgyökök által szabályozott sejti folyamatoknak jelenleg csupán töredékét ismerjük, és meggyőződésem szerint ez a viszonylag új kutatási terület a jövőben számos nagyon fontos eredményt közöl. Sok a kérdés, kevés az objektív válasz."

\footnotetext{
$\begin{array}{llll}\text { Haber-Weiss-reakció: } & \mathrm{O}_{2}+\mathrm{H}_{2} \mathrm{O}_{2} & \rightarrow & \mathrm{O}_{2}+\mathrm{OH}^{+}+\mathrm{HO} \\ \text { Fenton-reakció: } & \mathrm{Me}^{2+}+\mathrm{H}_{2} \mathrm{O}_{2} & \rightarrow & \mathrm{Me}_{3}++\mathrm{OH}^{+}+\mathrm{HO}\end{array}$
}

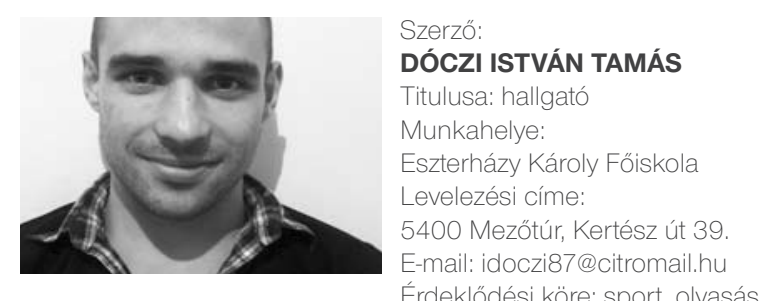

Társszerzó: Esterhézy Károly Föiskola
E-mail: pritz@othail.hu
A szabadgyökök külső és belső tényezők, biotikus és abiotikus stresszhatások következményeiként is indukálódhatnak (Benzie, 2000). Sejten belüli források lehetnek a hemoglobin, riboflavin, flâno (Toporcov és mtsai., 2004) közül megemlithető többek között:

" az ultraibolya és radioaktív sugárzás,

a dohányfüst, szmog,

a túlzott alkoholfogyasztás

a stressz (munkahelyi, szociális stb)

" a vegyi anyagok,

környezetszennyezés,

" toxinok.

A keletkező szabadgyökök a lipideket alkotó zsirsavmolekulákat, a szénhidrátokat, fehérjéket és nukleinsavakat is károsithatják gyökös mechanizmusú láncreakcióval. A lipidek károsodása a lipidperoxidáció, amely során elsősorban hidro-peroxidok keletkeznek, amelyek agresszívan támadják meg az egyéb molekulákat mint az enzimeket, fehériéket és aminosavakat stb. (Cadenas, 1989; Djuric és mtsai, 1998; Heinonen és mtsai. 1998). Következményként a membránok killyukadhatnak, felszakadhatnak, ami a destruktiv lizoszómás enzimek kiszabadulását eredményezheti, így a szövet károsodhat (Lugasi és Blázovics, 2004). A lipidperoxidáció következtében esszenciális zsírsavhiány alakul ki, amely kárositja a membránok (elsősorban a mitokondrium, lizoszóma, plazmamembrán) finom szerkezetét, funkcióját, zavart okozhatnak a sejtek közötti kommunikációban, végső esetben a sejtek nekrotikus pusztulásához vezethetnek. A szabadgyökök okozta károsodásokkal szemben összetett, integrált védelmi rendszer biztosítia a sejtalkotó molekulák védelmét (Benzie, 2000).

Az antioxidánsok olyan molekulák, amelyek csekély menynyiségben vannak jelen az oxidálandó szubszzráthoz képest, és jelentőss mértékben csökkenteni vagy akár gátolni is képesek annak oxidációját (Halliwell és Gutteridge, 1995). Az antioxidánsok lehetnek lipofilek (E-vitamin, B-karotin, A-vitamin), hidrofilek (C-vitamin, aminosavak, polifenolok), citoszol antioxidánsok (Q10 koenzim), valamint szerkezeti antioxidánsok (nyomelemek, szelén, cink, aminosavak, szelenocisztein) (Cornetti, 2009). Emellett létezik 
„az antioxidánsok jótékony hatással vannak az életünkre, és segitségükkel könnyebben kivédhetjük a napjainkban olyannyira terjedő különféle civilizációs betegségeket. Itt fontos szerepet kap a testmozgás, ugyanis

ekkor fokozódik a szabadgyöktermelés,

majd védekezésképpen antioxidánsok keletkeznek, ami a késöbbiekbe ellenállóbbá teheti az emberi szervezetet.

\section{밈}

Abstract: Free radicals are naturally presen in our lives being and are generated internal and external circumstances. For instance, an internal source can be abiotic stress whereas external ones are considered to be various stress effects like environmental pollution or smoking. Antioxidants provide proper protection against free radicals. Some of them are generated by the human body, other not necessary attained through food only Important antioxilants are Vitamin $C$ V Vitamin $E$ and carotenoids. Fruits also contain a high level of antioxidants. Interestingly free radicals are not only senerated by harmful effects but exercising can also lead to a high rate of free radical generation. Meanwhile, as a respond, the formation of antioxidants is also initiated automatically, making the human organism more resilient. Recently a number of methods became known in connection with the analysis of free radicals in comestibles and different biological systems that have hundreds of different variants known to date. We can divide them into two major groups: the methods related to hydrogen transition and the methods of electron transition. Nevertheless, antioxidant intake should be handled with consideration since too high antioxidant level can lead to an imbalance in the human immune system. On the other hand low intake can decrease the chance of preventing diseases. Beneficial effects of the antioxidants were also proved and supported by several studies. As an example, the so called life crystals elixi made from natural ingredients with high antioxidant content had a positive effect on the flexibility of the veins indicated in $80 \%$ of the patients. Keywords: Antioxidant, free radical olyan csoportositás is, miszerint az antioxidánsok vagy láncreakciót megszakití́ (elsődleges), mint például a C-vitamin, a húgysav, vagy edo (masodlagos) antioxidansok k lentetnek, mint a transzterin vagy a polfenolos vegyuletek (Apak és misai, 2007). A vedóhatásukat a femion kelátorok például a Fenton-reakció gátláá́val fejtik ki, amely vegeredmenyekent a rendkival agressziv hidroxigyok ke

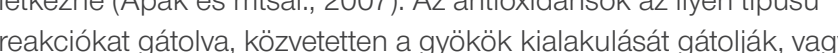
magukat a gyököket képesek megkötni Meg kell jegazni hog a gyök befogáśra ló képesséc az antioxidán konoentráiog

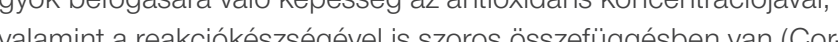
netti 2009) A rondszergver szor álitani , (enzimatikus rendszer elomei) azonban számos molk nún

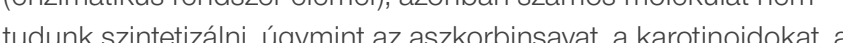

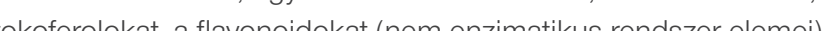

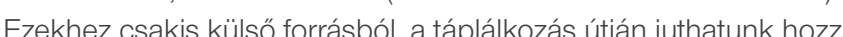
(Vertuanies mis kil, 2004). Az emberiszervezetben az entioxidán-

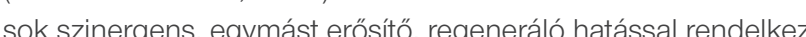
nek, így az antioxidánsok együtt jóval hatékonyabbak a szabadgyökökkel szemben, mint külön-külön (Balogh, 2010)

TERMÉSZETES ANTIOXIDÁNSOK

Természetes antioxidáns vegyületek a C-vitamin, E-vitamin, karotiTermeszzetes antioxidans vegyuletek a C-vitamin, E-vitanin, karotés Kalt, Forney, Martin (1999) megielent mǘében mintegy erös es Kaxioxidáns vegyületek a gyümölcsök. Például, fontos antioxdáns tevékenységet fedeztek fel a bogyókban, cseresznyében, citrusban, kiviben aszalt szilvában és az olajbogyóban, nagy aktivitású antioxidánsokat találtak az olvivalajban és a gÿ̈mölcslevekben. A sokféle zöldség és különösen a kaká́bab a burgonya, a hüvelyesek, természetes kivonatok és kereskedelmi termékek, a fokhagyma és a gyömbér a borok tartalmaznak számos polifenol-vegyületet (Andrés Moure, Jose M. Cruz Danie Franco, J Manuel Dominguez, Jorge Sineiro, Herminia Dominguez, María José Núñez, J. Carlos Parajó, 2001).

Antioxidáns szer hatásának bemutatása Az Életkristály magas antioxidáns-tartalmú, természetes alapanyagokból készült, gyümöllss-növény elixir! Színes gyümölcsök (szölő, málna, sárgabarack, szeder, cseresznye), illetve, zöld tea, kamilla, jázmin kivonatát tartalmazza, valamint adalékként mézet is. Ezen összetevők magas polifenol-tartalmuk révén rendelkeznek antioxidáns tulajdonsággal. A vizsgálatokban 57 fő, a vizsgálatokra önként jelentkező személy vett részt (14 férfi és 43 nó). Átlagéletkoruk 49,75 $\pm 10,4$ év volt. A vizsgálatok elött a kutatók felmérték a személyek egészségi állapotát és alap állóképessé gét kikérdezéssel, arteriográfiás és futószalag-ergometriás vizsgálat segítségével. Az így kapott adatok alapján kiválasztották a 15 legrosszabb érállapotú személyt.

A TensioMedTM Arteriográf az artériák állapotának gyors vizsgálatára alkalmas, teljesen új elvek alapján müködő müszer. A felkarra megfeleló nyomásra felfújt mandzsetta segítségével a vérnyomásméröre emlékeztetổ készülék olyan, a szivmüködéssel kapcsolatos mechanikus jeleket mér, amelyeket eddig még nem használtak a diagnosztikában. Ezek a jelek tájékoztatást adnak az erek rugalmasságának mértékéról, annak egészséges vagy kóros voltáról. A vizsgálat révén kapott paraméterek közül kiemelkedō az ún. augmentációs index (Alx) és a pulzushullám terjedés sebessége (PWV). Az Alx az elsődleges (korai) és másodlagos (visszavert, reflektalt) systolès nyomáshullam különbségének es a pulzusnyomas hanyadosananak százalékos aránya. Az egyén edzettsegi allapotanak, terhelhetósegenenek, legzésfunkciójának megallapitasaara szolgal a futoszalagergometriás vizsgálat. Segitségever megallapitható, hogy adott protokoll szerint elvégzett terhelés esetén mekkora a vizsgatl szemely oxigenfelvétele, terhe lés kozbeni vernyomasertékel, puzusszáma, RQ-erteke, a végzett munka mennyisege, anaerob munkavégzó kepessege stb. A kivalasztott 15 to esetén az atlagos eletkor magasabb volt, jelezve, hogy az erek rugalmasságanak méteke az eletkor novekedésével attalababan romilik. A BMI ertéke 24,7, a normál tartomanyba

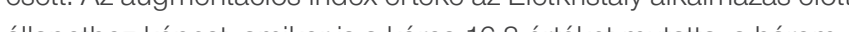

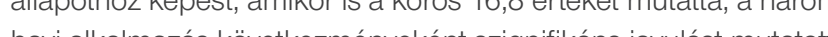

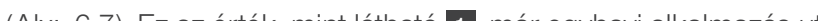

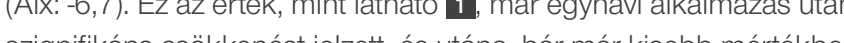

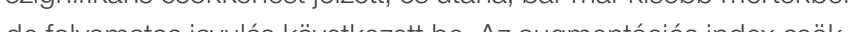

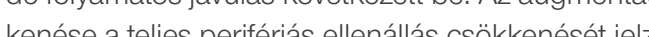

A fố ütóér pulzushullám-teriedési sebessége a kezdeti $8,9 \mathrm{~m} / \mathrm{s}$ értékröl az Életkristály háromhavi alkalmazása után $8,3 \mathrm{~m} / \mathrm{s}$ értékre csökkent. A pulzushullám teriedési sebességének csökkenése az erek rugalmasságának növekedését jelzi. 2

A futószzalag-ergometriás vizsgálat eredménye azt mutatia, hog a háromhavi alkalmazás során az oxigénfelvétel nem vátlozotti de a felvett oxigén kihasználtsága javult.

Osszességében elmondható, hogy a három hónapon keresztü alkalmazott Eletkristály ́́trendkiegésźtő a vizsgált szenélyok 80 százalékénát okozott javulást az augmentácós index érćkében. Ebből 60 százaléknál kiemelkedő mértékü, míg 20 százalákná jelentősen nagymértékü volt a változás. 20 százalékban nem mértünk változást. A vizsgált személyek szubjektiv élménye és a beszélgetések alapján elmondható, hogy egy fŏ́ Kivételével mindenkinek jobb lett a közérzete, kevésbé volt f́érákony jobba birta a terhelést (Sző́ts Gábor, Petrekanits Máté, 2006).

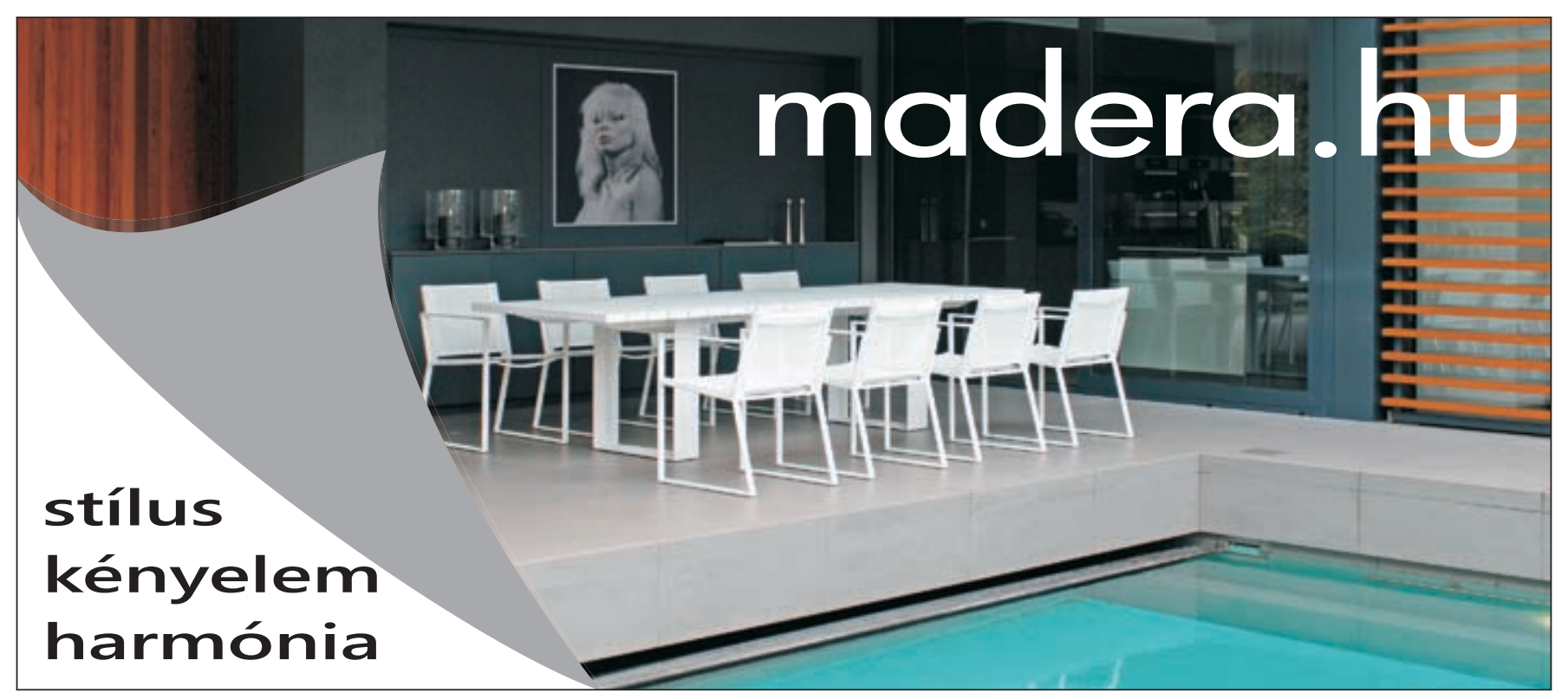

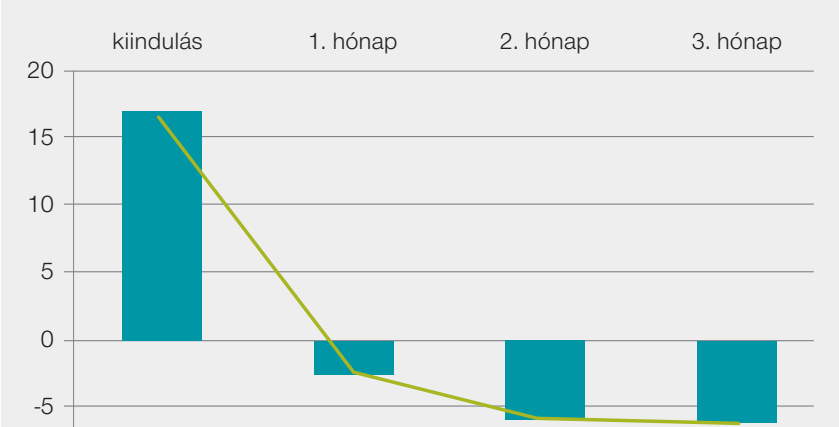

11 Az augmentácios index valtozasa az Elettristály 3 havi alkalmazasa orán. (átlag) $\left({ }^{*} \mathrm{p}<0,05\right)$

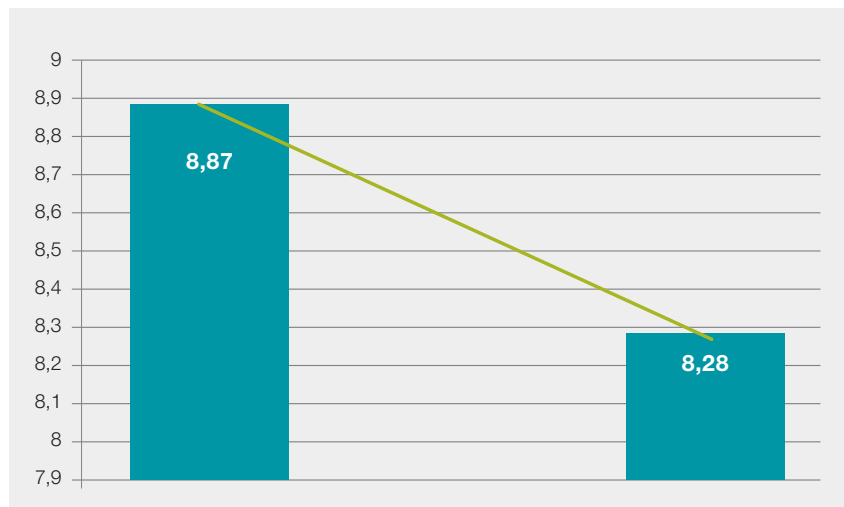

2 A pulzushullám teriedési sebességének valltozása az Élettristály 3 hav szedése során 


\section{ANTIOXIDÁNSOK MÉRÉSE}

Az elmúlt években megnőtt azon kutatások száma, amelyek a különböző élelmiszerek, biológiai rendszerek természetes antioxidánsaival és mérésükkel kapcsolatosak (Frankel és Finley, 2008; Gokmen és mtsai., 2009). Az antioxidáns-kapacitás az adott rendszerre vonatkozó összes antioxidáns vegyület együttes hatását jelenti.

Az eddig kifejlesztett mérési módszereket csoportosítani lehet (Frankel és Meyer, 2000):

» Hidrogénatom-átmenettel (HAT-hidrogen atom transfer) és

»Elektronátmenettel (ET-elektron transzfer) kapcsolatos módszerekre.

\section{Hidrogénatom átvitelén alapuló, antioxidáns- kapacitást mérő módszerek bemutatása} Oxigéngyök-abszorpciós kapacitás - ORAC - Oxygen Radical Absorbance Capacity. Az ORAC módszert Cao és munkatársai fejlesztették ki 1993-ban. A mérés során a próbamolekula (fehérje) a peroxilgyökökkel (ROO.) reagálva oxidatív sérülést szenved, ezért az általa kibocsátott fluoreszcens jel intenzitása csökkenni fog.

\section{Elektronátmeneten alapuló antioxidáns- kapacitás-mérési módszerek}

Réz-ionredukáló képességen alapuló antioxidánskapacitás-mérés - CUPRAC - CUPRIC ion Reducing Antioxidant Capacity.

A módszer Apak és munkatársai (2007) nevéhez füződik. Redukálóképességet határoz meg ez a metodika is. 7-es pH-n 450 nm-en. A reakcióidő 30 perc. Olcsó, egyszerű, nem igényel drága felszerelést. Víz-, zsíroldható és tiol típusú antioxidánsokat is képes mérni (Balogh, 2010).

\section{FELHASZNÁLT IRODALOM}

» Szőts Gábor, Petrekanits Máté (2006): Egy antioxidáns szer hatása az erek állapotára. Magy. Sporttud. Szemle, Budapest, 3:37-41.

» Radák Zsolt (2006): Szükséges-e az antioxidánsbevitel? Magy. Sporttud. Szemle, Budapest, 3: 36-37.

» Liang Shen, Hong-Fang Ji, Hong-Yu Zhang (2007):How to understand the dichotomy of antioxidants. Biochemical and Biophysical Research Communications. Pages 543-545

" Andrés Moure, Jose M. Cruz, Daniel Franco, J. Manuel Domínguez, Jorge Sineiro, Herminia Domínguez, María José Núñez, J. Carlos Parajó (2001):

» Natural antioxidants from residual sources. Food Chemistry, Pages 145-171

» Simon Y. L. Ching, Jon Hall, Kevin Croft, John Beilby, Enrico Rossi, Emilio Ghisalberti (2006): Antioxidant inhibition of oxygen radicals for measurement of total antioxidant capacity in biological samples. Analytical Biochemistry, Pages 257-265

» N. Nenadis, I. Zafiropoulou, M. Tsimidou (August, 2003): Commonly used food antioxidants: a comparative study in dispersed systems. Food Chemistry, Pages 403-407

" Radák Zsolt (2008): Szabadgyökök és testedzés: jelen- és jövőbeli perspektívák. Magy. Sporttud. Szemle, Budapest, 2: 11-15.

» Balogh Emőke (2010): Antioxidáns-kapacitás meghatározása és ennek kialakításában szerepet játszó vegyületek vizsgálata bogyós gyümölcsök esetében. PhD-értekezés, Budapest

\section{A SZABADGYÖKÖK ÉS A TESTEDZÉS}

Szoros a kapcsolat a sejtek metabolizmusa és a képződő szabadgyökök között, hiszen a sejtekben az egyik legnagyobb gyöktermelő a mitokondrium, melyben az aerob energianyerés során szabadgyökök is képződnek. Az első testedzéssel kapcsolatos vizsgálat jelentős mennyiségű szabadgyököt mutatott ki a vázizom mitokondriumában a kimerülésig végzett futás hatására, melyet elektron spin rezonanciával vizsgáltak (Davies et al., 1988). A mozgás következtében hatékonyabban lebontott fehérjék csoportjához tartozik a beta-amyloid, melynek a felszaporodása az Alzheimer betegség oka, és ennek a betegségnek nagyon súlyos funkcionális következményei vannak (Lazarov et al., 2005). Hasonlóan fontos szerepe van a testedzésnek a Parkinson-kór esetén is. Mindkét betegség jelentős oxidatív stresszt jelent az idegsejtek számára, és a testedzés által indukált magasabb aktivitású antioxidáns-rendszerek védelmet jelentenek (Radák, 2008).

Az antioxidáns-bevitel szükségessége kérdéses, hiszen szinte lehetetlen megmondani az optimális mennyiséget, a szabadgyökökből és az antioxidánsokból egyaránt. A szervezetünk nagyon okos, és az enzimatikus rendszerek harmóniában élnek egymással, nem véletlen, hogy a jelenleg ismert módszerek közül csupán kettő az, amely növeli az átlagélettartamot, az egyik a maximálist is, az olyan természetes módszer, mely növeli az enzimatikus antioxidáns és a sérülésjavító rendszerek aktivitását. A kettő közül az egyik, mely embereken is müködik - az a rendszeres testedzés! Antioxidáns-bevitelt számos antioxidánst gyártó cég javasol. Lehet, hogy igazuk van, de lehet, hogy nem. Ha hiány van, kell az antioxidáns. De mennyitől is kezdődik a hiány? A szabadgyökök által szabályozott sejti folyamatoknak jelenleg csupán töredékét ismerjük, és meggyőződésem szerint ez a viszonylag új kutatási terület a jövőben számos nagyon fontos eredményt közöl. Sok a kérdés, kevés az objektív válasz. Úgy gondolom, hogy itt tartunk ma, lassan már tudunk kérdezni, de a válasszal még gondok vannak (Radák, 2006).

\section{KÖVETKEZTETÉS}

A hazai és a külföldi szakirodalom alapján összességében elmondható, hogy az antioxidánsok jótékony hatással vannak az életünkre, és segítségükkel könnyebben kivédhetjük a napjainkban olyannyira terjedő különféle civilizációs betegségeket. Itt fontos szerepet kap a testmozgás, ugyanis ekkor fokozódik a szabadgyöktermelés, majd védekezésképpen antioxidánsok keletkeznek, ami a későbbiekben ellenállóbbá teheti az emberi szervezetet.

A rendszer egyes elemeit maga a szervezet is elő tudja állítani, azonban számos molekulát nem tudunk szintetizálni, úgymint az aszkorbinsavat, a karotinoidokat, a tokoferolokat, a flavonoidokat (nem az enzimatikus rendszer elemei). Ezekhez csakis külső forrásból, a táplálkozás útján juthatunk hozzá (Vertuani és mtsai., 2004). A dolgozatot ajánlom a téma iránt érdeklődőknek, illetve azoknak a sportszakembereknek, akiknek további kutatási alapként szolgálhatnak az itt összegyüjtött kutatások. 